\title{
Study Of Ki Hadjar Dewantara Opinion About Human Right And Shari'a In Perspective Theory Of Habermas Critic
}

\author{
Sita Acetylena \\ syahidahazahra@gmail.com \\ Department of Management Sekolah Tinggi Ilmu Ekonomi Jayanegara Malang, Indonesia
}

\begin{abstract}
The purpose of this study is to investigate and understand the thinking of Ki Hadjar Dewantara on Human Rights and Sharia in view of the criticism of Habermas's theory. In addition, to determine how thoughts affect Dewantara Ki Hadjar's struggle for independence movements in Indonesia. The research method chosen is qualitatif research, literatur study. Library is used as a sourced as a source of research are various works of Ki Hadjar Dewantara and writings related to Ki Hadjar Dewantara and writings related to Ki Hadjar Dewantara Thought on Human Rights and Sharia. Research results indicate that human rights and the law according to Ki Hadjar Dewantara an inseparable unity. Islamic law not just talking about the rules of worship, but also on deed-deeds of the so-called soul or essence. In thinking of Ki Hadjar Dewantara known that fighting for the independence of the inner and outer which is one of the values of human rights can only be done by the action of a true culture. The definition of action of a true culture is enlightenment movement is done through spiritual-based education rooted in Sharia such as "tawakal" and "manunggaling kawula gusti" to get human rights such as a freedom by communication action.
\end{abstract}

Keyword : Ki Hadjar Dewantara, Human Rights, Sharia

\section{INTRODUCTION}

Ki Hadjar Dewantara[1] was founding of Indonesia education and Indonesia crusader. He struggled the Independence in education by founding Taman Siswa Nasional Institution. Independence is major value of Human Right and it was purpose of Taman Siswa that discribed in Panca Darma, Taman Siswa Principle.

Therefore, the study will be conducted to know and understand Ki Hadjar Dewantara opinion about Human Right and Shari'a. Researcher assumed those was on Panca Darma Principle values, because as obedient Muslim and descent of Sunan Kalijaga and Pangeran Diponorogo so the assumption was fervently in the hypotheses. The study is expected can expose Ki Hadjar Dewantara Opinion about human Right and Sharia so that relation of those things can be found. Since Indonesia hadn't been independent yet, it had struggled

The study uses qualitative research. The recourses are Ki Hadjar Dewantara books and writings that related to Human Right and Shari'a.

Limitation of the study is theory critical from Jurgen Habermas perspective. So that the result perhaps can be reace the purposes of study in understanding Human Right and Shari'a on Social Science

\section{LITERATURE REVIEW}

Indonesia nationally moved with many ways, one of them were education. Ki Hadjar Dewantara and his friends allied in Paguyuban Selasa Kliwon ${ }^{1}$ militated imperialisms by education. Therefore, Taman Siswa principles that described in Panca Darma were laden with values to get independence. They believed that Independence was the right of country and human everywhere. It not only got independence as country but also as human to get education, prosperity and their right as that given by god.

\subsection{Ki Hadjar Dewantara}

Ki Hadjar Dewantara came to Europeesche Lagere School after graduated from Europeesche Lagere School. After that, he continued his study at STOVIA (School Tot Opleiding Van Indische 
Arsten) but he went off from his study. He also joined Teacher Training School called Lagere Onderwijs[1].

Ki Hadjar Dewantara and Tjipto Mangunkusumo at middle of July 1913 established "Committee tot Herdenking van Nederlandsch Honderdjarige Vrijheid" that called "Komite Bumi Putra". The committee would protest the celebration of Nederland Independence Day because Nederland forced people to collect money.

Soewardi, Tjipto Mangunkusumo and Douwes Dekker called "Indische Party" were arrested immediately because they protested by writing a lot of articles and brochures. In $18^{\text {th }}$ August 1913 . The country sent the letter of punishment to them. They arrested separately; Soewadji in Bangka, Tjipto Mangunkusumo in Banda Neira, Douwes Dekker in Timur Kupang. The punishment allow them went out from Nederland colony. They wanted to change the Interniran Punishment into Externir Punishment and chose Nederland as their proscription.

In Nedherland Soewardi Soejaningrat was also interested to education beside social and politic field. He studied education field at 1915 and got teacher certificate. He had already known the prominent figures in education such as; J.J. Rousseau, Dr. Frobel, Dr. Montessori, Rabindranath Tagore, John Dewey, and Kerschensteiner. Forbel was famed expert from German, founder of "Kindergarten". Montessori was academician from Italia, founder of "Casa dei Bambini". Rabindranath Tagore was famed poet from India and founder of "Santi Niketan" Instituation[2].

By Soewardi and his friend's experience in politic, they review the ways to get Indonesia Independence[3].The first Taman Siswa School was founded in Yogyakarta at $3^{\text {rd }}$ July 1922 and named Nationaal Onderwijs Instituut Taman Siswa by made a Kindergarten and teacher training. Soewardi taught in Adhi Dharma School that operated by his brother; Raden Mas Soerjopranoto, while he prepared to open new school that initiated by Paguyuban Selasa Kliwon.

According to Pronowidigdo, Paguyuban Selasa Kliwon was founded by Soetatmo Soeriokoesoemo and Ki Ageng Soerjomentaraman at the end 1921 that gather young Javaneses that had "revolutionary spirit". Meeting was conducted every 35 days in Selasa Kliwon Day in Soejomentaraman House[4].The members were Ki Ageng Soerjomentaraman, Soetatmo Soeriokoesoemo, Pronowidigdo, Prawirowiworo, R.M. Gondoatmodjo, B.R.M. Soebono, Soerjoputro, Soerjoadipoetro, R.Soetopo Wonobojo, Soerjodirdjo, and Soewardi Soerjaningrat[5].The members had relationship with Paku Alam family and Budi Utomo[5]. Meanwhile, Ki Ageng Soerjomentaraman as a leader was great person that born as prince of Yogyakarta but he refused his position in palace and lived as farmer[6].

The members had same spirit to return Javanese culture and independence that was confronting Nederland colonization. The spirit also influenced by "rediscover" East World. Eastern Philosophy talked about easterner that hunting for salvation in modern era, especially Tagore theory from India.

Soewardi influenced by Tagore who got Nobel reword at 1913 when Soewardi was at Nederland. His opinion about education was influenced by Tagore that conducted education well in Tagore school. When Tagore passed away in 1914, He wrote his biography in cemetery; he widely wrote about how Tagore influenced him and Taman Siswa. According to Soewardi, Tagore's ideas encouraged the easterner and changed European mindset about East[7]. That impressed him deeply and made him proud and confident to be easterner specially as Javanese.

\subsection{Habermas Critical Theory at Glance}

Jurgen Habermas is one of the experts of critical philosophy. The characteristic of his critical philosophy is that he is always related to criticism of real social relationships. His critical thinking reflects the society and himself in the context of oppression and emancipation structures dialectic. This philosophy does not isolate oneself under the branch of original theory. The critical thinking perceive that oneself is responsible for real social condition[8].

The stream of this critical thinking firstly developed in 1920s. The figures are Georg Lukacs, Karl Korsch, Ernst Bloch, Antonio Gramsci, etc. One of the streams in this critical thinking is Society Critical Thinking. This theory has developed since 1930s by some figures which worked in Institut fur Sozialforschung in University of Frankfurt. They are Marx Horkheimer, Theodor W. Adorno and Herbert Marcuse and the other members of the group. This group is then well-known as "Mazhab Frankfurt"[8]. 
As the one who is inherited the critical theory, Jurgen Habermas is also the reformer of this theory. Although he is no longer considered as the one who belong to Mazhab Frankfurt, his research field tend to reborn the "Frankfurt" paradigm for the philosophy and other social sciences in general.

In the Habermas's concept, Critical Theory is defined as an empirical historical philosophy to achieve practical purpose. It is empirical and scientific but it does not refer back to the empirical-analytical sciences; the philosophy here means critical reflection which is not included in determining the basic principles; historical but avoiding to be historicity; and also practical which means directed to political-emancipatory action[9].

\subsubsection{Science and The Freedom of Value}

The main problem is whether science particularly social sciences must work with the freedom of value. Those who are pro with the freedom of value give affirmative response in that case. They even give additional explanation that the methods which are used in natural science are the same as the social sciences. Therefore, it means that social science should make general rules and scientific predictions as in natural sciences if they want to be the same as natural sciences. A scientific explanation should not stand in one side and give any judgment. Based on this opinion, they are who pro to the freedom of value are considered as positivism party[10].

According to Habermas, every scientific research is directed by certain human vital interests (both in natural and social sciences). Therefore, the postulate of the freedom of value is "illusion" not only for social sciences but also the natural sciences. Ignoring the values of facts is the same as contradicting Sein (exist) which is pure and Sollen (should) which is abstract.

In the definition of interest and directing knowledge, it covers two moments: knowledge and interest. From daily experiences, it can be known that ideas are often functioned to direct the actions or it is a motive justification of actions. What is called as rationalization in certain level is called as ideology when it is in the collective level[10].

In the final section of his essay about Dogmatism, Reason, and Decision, Habermas suggests that only ratio which is fully aware of the interest in the reflection improvement to autonomy and responsibility, which continuously think in very rational discussion that will get the transcendent power of its materialistic engagement. What is meant here is ratio which does selfreflection (critical) with the support of interest to detach himself from the internal and external obstacles from the knowledge subject which is emancipatory interest[11].

In further, Habermas differentiate four levels of rationalization. First, rationalization opens the possibility of empirical sciences methodology application in rational attitude to realize targets. Second, rationalization covers options of the techniques to implement. Technical considerations are understoodas praxis, namely technology and social system industry. In these two levels, normative values are neglected and considered as irrational values but to have a technical choice which is in line with technologically rationality, it needs decision theory and it has implicit values, namely "economical" and "efficient." Third, rationalization is understood as the efforts to get the control of certain processes with scientific prediction. In this third level, Habermas claims that the values are not neglected but it is even determined. Fourth, rationalization covers the understanding of the decision making into the machine. Machine will make the decision routine based on the values such as efficiency, effectiveness, productivity, and so on[11].

\subsubsection{Society, History, and Communication Paradigm}

The development of social philosophy has been done by the efforts of relating theory and practice since Marx's era. The problem is how the knowledge about society and history is not only contemplation, but also encouraging "social change practice". This practice is not a blind behavior because of an instinct, but also a human basic behavior as a social creature. Consequently, practice is enlightened by "rational awareness" because it is emancipatory. Habermas in his essay, Labor 
and Interaction: Remarks on Hegel's Jena 'Philosophy of Mind', says that Hegel understand practice not only as "work" but also "communication". Because practice is based on rational awareness, ration is not only visible in activity of conquering the nature with work but also in the "interaction inter-subjective" with daily language. Therefore, it is like work to make people distance from their nature. Language is able to make a direct distance from the perception so both work and language are not only related to practical but also rationality[11].

Habermas shows the weaknesses of the former philosopher because it does not only presuppose practice as work which is called "purposeful rational behavior", but also rationalization as "conquering the authority" or what he calls it as "subject-centered ratio". The process of being modern capitalist runs imbalance because it puts rationalization in the field of institutional working-framework or communication. This practice rationalization communication is the unique basic of Habermas' social theory[11].

Habermas accepts Marx's assumption that history runs based on certain developmental logic but he disagree if technology and economy of the society become the main stimulus of history development. What is called society production way by Marx, according to Haberman, is enabled by society's learning process of practice-moral dimension which is the organization principles. In short, capitalism is a case in social evolution; and in that case, the principles of capitalist organization enable economy and technology to set up the social interaction. Since capitalism is only a case, the role of technology and economy cannot be generalized universally for any era and any kind of social formation. By the assumption which perceive that society is basically communicative, Habermas then change the production paradigm from historical materialism into a communication paradigm. As a change of the production way's role, he put the role of social communication structures as priority in the social change[11].

According to Habermas, these communication structures are more appropriate for the society than the production ways because production ways which involves technical dimension learning process is controlled by communication structures. Authority rationalization at its turn rises up the issue of democracy in the form of general and public communication which is free and guaranteed institutionally. In the Haberman's point of view, it is only authority which is determined by the critical public discussion which is rationalized authority.

In modern politics, it is only "pragmatic" model which relates to democracy. In this pragmatic model, tight separation of the experts and politicians' role are changed by "critical interaction". This model enable reciprocal or two ways communication between experts and politicians which is in certain turns the experts can give scientific advices to make a decision, and politicians discuss with the experts based on certain practical needs. This kind of communication is drawn as communication which is not based on authority legitimacy ideology but a normative scientific discussion. Critical interaction unsure in this politics is perceived by Habermas as real possibility for authority rationalization in the society nowadays[11].

This kind of rationalization is called as practice-ethic rationalization which is in classical understanding -Aristoteles thought- politics relate to ethic: a doctrine about a good and fair life in "polis" or society[11].

\subsubsection{Habermas's alternative: Communicative Ratio and Enlightment}

Habermas argued that critic will progress with the basis of "communicative ratio" which is understood as "communication practice or communicative action". He underlines that the society is essentially communicative and not only the development of production and technology power is determiner the social changebut also "learning process in a practice-ethical dimension". In the communicative ratio cases, attitudes objectify that makes the knowledge subject views themselves as entities in the outside world is no longer special. Ambivalent relationship subject to himself (see themselves as well as free subjectivity and also objectified self who enslaves) is destroyed by inter-subjectivity. The ratio is not assimilating with the authority. Therefore, the ratio that stands on the subject, including in mixing (amalgama) both knowledge and authority, can be destroyed by the ratio of communicative inter-subjectivity[11]. 
Based on the new paradigm above, Habermas wants to maintain the normative content that is contained in modernity and cultural enlightenment. The normative content of modernization is of what he calls rationalization of the world-life that based on a communicative ratio. The world life consists of culture, society and personality. Rationalization of the life-world is possible through communicative action.

Rationalization will produce three sides. First, although the new situations would always arise, cultural reproduction will still ensure the continuity of tradition and coherence adequate knowledge to requirement of a consensus in the daily practice. Second,social integration ensures that in the new situationsthe actioncoordination will be maintained with facilities of interpersonal relationships which are regulated legitimately by constancy of group identities remained there. Last, the socialization which ensures in the new circumstances the acquisition of general ability to act for the future generations is still secure and the harmonization of individual life history and collective life are maintained[11].

Those three sides ensure that the new situations can be connected with what is in this world through communicative action. In that communication, participants performed a satisfactory communication. The participants want to make his interlocutors understand his point by trying to achieve what he calls "kalim-klaim kesahihan" (validity of claims). The claims that considered rational and will be accepted without coercion as a "consensus", in his book The Theory of Communicative Action, Habermas said four kinds of claims. If there is agreement about the world of scientific and objective, it means achieving "truth claims" (truth). If there is agreement about implementation of norms in the social world, means achieving "claims accuracy" (rightness). If there is agreement on the uniformity between the inner world and expression of one's, it means achieving "claims of authenticity or honesty" (comprehensibility). Every effective communication must reach all four claims, if they are able to do that, it means they have "communicative competence".

Communicative society is not a society who does criticism through violent revolution, but to give argumentation. Then, Harbemas differentiates argumentation into two kinds: conversation or discourse (discourse) and criticism. Doing conversation if presupposes the possibility to reach a consensus. Although, it is intended for consensus, communication can also be disrupted, so it does not require imagining the consensus. In this case, Habermas prioritizes criticism. He divides criticism into two kinds, namely: aesthetic criticism and therapeutic criticism. Aesthetic criticism, if the social norms that considered to be objective would be disputed. If practical discourse supposes the norms of objectivity, criticism in this case is a question their compatibility with the appreciation of the inner world. In the other hand, we can call it as therapeutic criticism when it is intended to reveal the self-deception of each side that communicates.

The communication paradigm occupies in the center of Habermas's thought in his effort for doing social change. In the language of Kant, communication is categorical imperative that marginalizes the centrality of the subject, because the communication paradigm by itself means prioritized the existence of inter-subjective relationship.

\section{RESEARCH METHOD}

The research method chosen is qualitative research, literature study. Library is used as a sourced as a source of research are various works of Ki Hadjar Dewantara and writings relate to Ki Hadjar Dewantara Thought on Human Rights and Sharia.

\section{RESEARCH RESULT}

Ki Hadjar Dewantara is someone that advocates the human rights primarily on equality, especially as he stated that: 
"Aku adalah orang Indonesia biasa.

Yang bekerja untuk bangsa Indonesia.

Dengan cara Indonesia"[12]
"I am an ordinary Indonesian.

Who worked for the Indonesian people

By means of Indonesia "

Ki Hadjar Dewantara is a noble. He is the grandson of a king. However, he threw the title of nobility and chose to be Indonesian ordinary because he was advocating the equal rights and equality. A statement of Ki Hadjar Dewantara is loaded with the value of equality as Indonesian people who want the same as other people. When he was 40, Raden Mas Soewardi Surjaningrat changed his name into Ki Hadjar Dewantara on the date of May 2, 1928.

Soewardi releases the titles of his nobility, Raden Mas, and start a new name. "Ki" means the same as "Kiyai" as the definition of Ki Hajarhimself[13]. As a term of honor for the elderly of Java, "Kyai" is also the title of the people who are respected since he has been found the nature of the human beings and religion is also in many ways the term for religious leaders in village and heads of boarding schools (pesantren).

Before Soewardi, Ki Ageng Soerjomentaraman, the leadership of Paguyuban Selasa Kliwon, he has been using the title "Ki". Born as the son of the king of Yogyakarta (his father was Sultan Hamengkubuwono VII), Soerjomentaraman releases his position and leave his palace to live in the countryside as a farmer. He founded the association SelasaKliwon with Soewardi and some friends. What he wants is wisdom, away from selfishness to gain true happiness and peace of soul.

"Hadjar", the second element in the new name of Soewardi same as ajar (teaching), a teacher in a dormitory or cottage. Meanwhile "Dewantara" literally means "intermediary of god". The meaning of the word "god" could be interpreted as God is one that protects all heroes and which define roles and their fate, which is known as Sang Hyang Wenang or Sang Hyang Tunggal. $\mathrm{He}$ is the master of the universe, the source of all power and the owner of space and time.

In short, the meaning of the name Ki Hadjar Dewantara shows how he defines himself as kiyai who teaches such as Semar, trying to convey the wishes of God to humans. The name also has the meaning as a teacher who acts as an intermediary Lord that conveys the goodness and the truth. Dewantara also defines the meaning of his name in the Wasita magazine as a true pandita who has knight character and ready as a protector of the nation and his people[14].

The change of name from R.M. SuwardiSurjaningrat of Ki Hadjar Dewantara through Wasita magazine is a way for conveying discourse on society, especially the intellectual community and the Dutch imperialists. Ki Hajar makes an alteration by doing new discourse about him which means make people of Indonesia and the Dutch know that he was ready to serve ibupertiwi and ready to fight together with people to achieve independence. This is very appropriate with Habermas's critical theory of communication actions, players interact, argue and communicative, and at the same time producing a definition of common situation. This definition such as part of people's live; and if they had been produced and reproduced through communicative action, then they are the basis of rational and integration of the society without pressure. For Habermas, the life of the world is a transmission in a cultural manner and understanding that organized in a linguistically manner. The life of the world is the world in a perspective view of participant players, and is structured by symbols that have meaning, communication through action verbal that oriented of comprehension / understanding. Coordination and integration of actions build consensus that is developed in a communicative manner through recognition of the validity verbal statement. In this context, Turner emphasized on three components of culture life, society, personality was added by suitability society needs cultural reproduction, social integration, and the formation of personality trough three-dimensional which the act of communication was existed to reach understanding, coordination interaction, and socialization.

This kind of definition is a part of social life. If it is already produced and reproduced through communicative measure, later on they will become the basis of pressure-less society's 
rational and integration. For Habermas, worldly life is a culturally transmission and pattern definition which is organized linguistically. Worldly life is a world of agent's perspective and it is structured by meaningful symbols, communication through verbal measure which is oriented on comprehension. Coordination and measure integration build consensus that is developed communicatively through the validity of verbal statement. In this case, Turner focuses on three life components, they are: cultural reproduction, social integration, and personal formation through three dimensions where communication measure made reach the definition of comprehension, interaction coordination, and socialization.

Ki Hadjar Dewantara's writings as the communicative measure which are the defense curves for the sake of individual independence goal. Nation independence is a measure that roles in Indonesia transition movement to become the free nation. It also inspires and composes public discourse that forces Indonesians' revival to fight for their rights as part of world nation; the right of living, the right of freedom, the right of participating in that politic harmonizes with the international right values.

Literally, human right can be defined as the rights that own by someone as their existence as human. These rights came from human's moral thought and it is needed to save the level and status of someone as a human. In another word, human right generally can be defined as the rights that stick on all of human beings so that their existence can be acknowledged without differing their sex, race, skin, language, religion, politics, nationality, wealth, and born[15].

Human right issue is a humanity petition. Nowadays, human right has become a written law concept. For instance, in England there are Magna Charta 1215 and Bill of Rights 1689, in United State of America there are Virginia Bill of Rights 1776 and Declaration of Independence 1776, in Africa it there are African Charter on Human and Peoples Rights, and also the World Nation has established the Declaration of Human Rights 1948. In this World Nation's declaration, it is confessed that a person carries the status as international law subject beside the state.

Generally it standardized on amount of declaration and covenant that deal with human right released by World Nation. There are three human right generations; the first is comprehension of written human right in Universal Declaration of Human Rights 1948. It is a declaration of human right which is influenced by west traditional perspective that popped up from a glory of triumph class toward absolute monarchy. The second is the comprehension of human right that is poured in Covenant on Civil and Politic Rights and Covenant on Economics, Social, and Cultural Right (1966). It is the result of the compromise of liberalism that emphasis on politic rights toward communism that emphasis on economic rights. In this second generation of human right, it is showed that there is an attempt of adjustment between individual right and collective right like the right of worthy life and right of getting education. It is poured also the right to wealth regulation and national resources independently as what has been written in both covenants.

Nevertheless, the existence of distinction of civil right and politic with economic right and social still causes assorted perception toward the cause of human right contravention. West nations believe that human right contravention is only about the contravention of civil and politic rights especially toward individual right of freedom. In another side, developing countries prefer to construct the economic, social, and culture rights.

The third is the comprehension of Declaration Vienna 1993 which is a compromise between west developed nations and developing countries. The recent from this latest generation is the existence of right of construction to sustain a culture and environment of certain society. In Vienna's conference, there is an agreement to balance the approach in order to develop and shelter the human right.

Essentially all of human right categories are universal, reliant, and intertwined. From now on, the international societies have to treat human right rightfully and equally based on the same status unity and accentuation. But it needs to be realized that it is not a final decision that demands without noticing space, time, ambition, law, and related nation importance, there will be appear new human right declarations that fix previous declarations. 
Perguruan Taman Siswa, an interesting concept was studied by Ki Hadjar is relevant to international human right values. It is also well known as "Principle of 1922". Through the concept, Ki Hadjar Dewantara seemingly wanted to express that the efforts of educating the societies' live have to have strong foundation. These Taman Siswa ideologies reflect the values of international human right.

The Taman Siswa[16] and its explanation can be seen as follows:

\section{a. Nationality Ideology}

The Taman Siswa should not be crashed with humanity, yet it should be the model of real humanity. It means that it implies no hostility with other nations but implies the sense of one to own nation; sense of altogether of joy and sorrow and a sense of being one in leading to both physically and spiritually happiness across the nation.

\section{b. Culture Ideology}

The Taman Siswa means to bring the nationality culture to the development that suits to the intelligence of the era, world development, and needs of societies both physically and spiritually in every era and condition.

\section{c. Freedom Ideology}

It has to be interpreted as the discipline by ourselves on the basis of the value of the high life, whether as the individual or member of society, so that the liberty has to be a tool to construct a strong individual that aware of balance environment and be able to be in harmony with the society where they live in.

\section{d. Humanity Ideology}

It stated that everyone's deed is to actualize the humanity which means the higher of human development both physically and spiritually and also the human development can be seen from their pure heart and the existence of love toward human and god's creatures. The love which means a belief of the existence of law development that covers the universe. The basic of human compassion should be seen also as a conclusion to struggle from the development's hindrances to the universe's will.

\section{e. Nature Authority Ideology}

Essentially it means that human as a creature fits to the universe. They cannot be separated from god's intention. Human can be living happily if they can merge with nature's authority that contains the improvement. It can be compared as a growing seed that grows to be a big tree. It grows and spreads continually.

Taman Siswa which was launched on July 31922 was legalized in Taman Siswa

Conference I on October 20-23 1923 and was stated in Taman Siswa Congress I as "Piagam Perjanjian Pendirian"[17]. It emphasizes that those foundations should be alive continuously and cannot be changed, ignored, and edited by other rules or other Taman Siswa cultures as long as it still uses Taman Siswa as the name.

To understand dedication and also the struggle of Taman Siswa, the students should understand the meaning of the basis and foundation of it. It works also for the teachers and other daily officers so they can interpret further so they will be successful in doing their dedication and realizing the idea of Taman Siswa.

Grounded on Islamic Shari 'a Taman Siswa foundation which is tawakal[18] and 'manunggaling kawulo gusti'[18], both of them are Islamic values sourced from Al-Qur'an and Al-Hadist. Ki Hadjar Dewantara strived to put them in to realize the inner and outer independence idea that regards as one of the Human Rights. 
The explanation about tawakal and manunggaling kawulo gusti were taught by Ki Hadjar Dewantara through discourse addressed as the feedback letter toward Sir Jonkman, one of the Cristian leaders who questions about tawakal essence in struggling the independence done by $\mathrm{Ki}$ Hadjar Dewantara in Taman Siswa. It showed that Ki Hadjar Dewantara strived to shape the consensus hence all parties could understand and struggle together in realizing Indonesia Independence.

The human right values within the education employed in Taman Siswa have encouraged the change in Indonesia as the independent and sovereign country. The Taman Siswa and Taman Siswa principles have shaped Indonesians become well-educated in terms of their intellectual or even their inner soul. The education in Taman Siswa has produced students with the high values of PancaDarma which bring and encourage the Indonesian change.

According to Lyotard[19], change will happen as the real politic action is done; however, Ki Hadjar Dewantara has proved that the human civilization is not merely happened by the result of real political action. Instead, there should be real cultural action which is done. Real cultural action means the cultural education which humanizes human as mentioned in the Human Right principles. Technology and science is grown and developed as a result of the high degree of human cultural civilization. There must be rise of human civilization in order to produce the real man. It goes in a line with the Nietszhe's perception about the superman thought there is a bit differences. The real man or superman that author means here is the man who becomes the real man, this man is a leader, strong and understands every single drawback and excess hence possibly leads the change, faces the era problems and solid due to the high spiritual inside him. He has to recognize there is a superpower above his power. Every knowledge is just the discovery not the creation itself. There must be The Mighty who creates a creature, while a man just discovers. The power of man is still limited on no matter how great or super his power is. It remains limited and imperfect. Instead, the spiritual power of man will encourage him into the better civilization change. The Human Rights enforcement will be realized if it is based on the Shari'a and spiritual. Therefore, Human Right and Shari'a are basically interconnected each other.

Due to that reason, the Human Right enforcement which is currently undergone by countries especially Indonesia is ought to be made continuously and should not merely be done structurally; it also has to be done through the cultural action despite the fact that International Human Right enforcement which is encouraged by United Nations meets the obstacles especially due to the lack of the socio-cultural understanding. The change will only be made through the discourses about Human Rights in society. Moreover, many of the society members especially Islamic society are apathy toward the Human Rights. The Human Right application which applies Spiral Model of Human Rights Development has not yet plenary apparently.

Five stages of Spiral Model of Human Rights Development cover several phases, such as: repression, denial, tactical concession, prescriptive status, and rule consistent behavior[20]. This Human Right development pattern is boomerang effect in which the repressive domestic actors within a country possibly deal with the partnership among the transnational networks, such as: International Human Right regime, NGOs, and international organizations by mean of pressing the government in that country to change their action regarded to the International Human Right manifestation[20].

Nevertheless, the manifestation of Spiral Model of Human Rights Development above is often seen as the coercion model of western countries to implement the Human Right concept based on their own perception toward the other countries without concerning the varied histories, cultures, political systems, social and economic growth level, and other factors. Hence, it is absolutely impossible to manifest the Human Right concept based on the western perception toward the other countries. It is tantamount to disgrace the concept of Human Right itself.

\section{CONCLUSION}


Human Rights and Shari'a according to Ki Hadjar Dewantara is the unseparated unity. Regarding the Islamic Shari' a, it is not only talking about the rules of worships; instead, it talks about the inner practices that are called as "Hakikat" (nature). Based on his perception, it is known that the inner and outer independence which is one of the Human Right values will only be achieved through the real cultural action. The real cultural action is the enlightened movement that is done through the spiritual-based education which is sourced from Shari' a to earn the Human Rights in form of Independence.

Therefore, it is necessarily done the continuous cultural movement in form of cultural education that has been done by Ki Hadjar Dewantara. Within the education field, there will always be discourses aimed to encourage the society to have a critical thinking and support them to reach the shared ideals. Nowadays, it cannot be denied that there are number of different perspectives toward Human Rights especially for the Islamic society due to the fact that the Human Right itself is applied in sosio-cultural unfairness in a nation. However, it is necessary for every single man to deserve their Human Rights. The change is not necessarily always done through the real political action, but it also has to be done through the real cultural action. The real cultural action is an education which humanizes man and produces the real man who has been ready to become a leader relying on the Mighty Power.

\section{REFERENCE}

[1] D. Hajar, Bagian I Pendidikan. Yogyakarta: Majelis Luhur Persatuan Taman Siswa, 1962.

[2] Y. B. Suparlan, Aliran-aliran Baru dalam Pendidikan. Yogyakarta: Andi Offset, 1984.

[3] T. Muhammad, Perjuangan dan Ajaran Hidup Ki Hadjar Dewantara. Yogyakarta, 1963.

[4] P. Ki, Lahirnja Taman Siswa. Pendidikan dan Pembangunan Taman Siswa. Yogyakarta, 1976.

[5] T. Muhammad, Pahlawan,dan Pelopor Pendidikan Nasional. Yogyakarta: Majelis Luhur Persatuan Taman Siswa, 1968.

[6] S. Grangsang, Demokrasi dan Kepemimpinan: Kebangkitan Gerakan Taman Siswa. Jakarta: Balai Pustaka, 1992.

[7] D. Ki Hadjar, Hubungan kita dengan Rabindranath Tagore, Pusara 11 dalam Karya Ki Hadjar Dewantara, Kebudayaan. 1977.

[8] M.-S. Franz, Filsafat Sebagai Ilmu Kritis. Yogyakarta: Kanisius, 1992.

[9] B. H. FX, Mudji Sutrisno dan F, Para Filsuf Penentu Gerak Zaman. Yogyakarta: Kanisius, 1992.

[10] H. Jurgen, Ilmu Dan Teknologi Sebagai Ideologi. Jakarta: LP3ES, 1990.

[11] B. H. F, Menuju Masyarakat Komunikatif. Yogyakarta: Kanisius, 1993.

[12] S. Bambang, Ayahku Ki Hadjar Dewantara. Jakarta: Pustaka Sinar Harapan, 1989.

[13] D. Ki Hadjar, System Pondok dan Asrama, Wasita seri Pertama dalam karya Ki Hadjar Dewantara Bagian I Pendidikan. 1962.

[14] K. Tsuchiya, Demokrasi dan Kepemimpinan: Kebangkitan Gerakan Taman Siswa. Jakarta: Balai Pustaka, 1992.

[15] "Universal Declaration of Human Rights United Nation,” vol. 1, no. 2.

[16] D. Dewantara, TamanSiswa 30 Tahun. Yogyakarta: Majelis Luhur Perguruan Taman Siswa, 1952. 
[17] S. Ki, Ketamansiwaan I. Yogyakarta: Majelis Luhur Taman Siswa, 1982.

[18] D. Ki Hadjar, Bagian II Kebudayaanpada Bab Manusia dan Kodrat Alam. Majelis Luhur Taman Siswa, 1977.

[19] Lyotard, Kondisi Postmodern: Suatu Laporan Mengenai Pengetahuan. Surabaya: Selasar Surabaya Publishing, 2009.

[20] "Human Rights Research Group in Law and State,” vol. 59, no. 60, 1999. 